\title{
TDP-43 pathology occurs infrequently in multiple system atrophy
}

\author{
F. Geser*, J. A. Malunda*, H. I. Hurtig†, J. E. Duda†‡, G. K. Wenning§, S. Gilmanף, P. A. Low**, \\ V. M.-Y. Lee* and J. Q. Trojanowski* \\ *Center for Neurodegenerative Disease Research, Department of Pathology and Laboratory Medicine, Hospital of the \\ University of Pennsylvania, University of Pennsylvania School of Medicine and tDepartment of Neurology, \\ Pennsylvania Hospital, University of Pennsylvania School of Medicine, $¥$ Parkinson’s Disease Research, Education and \\ Clinical Center, Philadelphia Veteran's Affairs Medical Center, Philadelphia, \Michigan Alzheimer's Disease Research \\ Center, Department of Neurology University of Michigan, Ann Arbor, ${ }^{* *}$ Department of Neurology, Mayo Clinic, \\ Rochester, USA; and \$Neurodegeneration Research Laboratory, Division of Clinical Neurobiology, Innsbruck Medical \\ University, Innsbruck, Austria
}

F. Geser, J. A. Malunda, H. I. Hurtig, J. E. Duda, G. K. Wenning, S. Gilman, P. A. Low, V. M.-Y. Lee and J. Q. Trojanowski (2011) Neuropathology and Applied Neurobiology 37, 358-365

TDP-43 pathology occurs infrequently in multiple system atrophy

\begin{abstract}
Aims and Methods: The $\alpha$-synucleinopathy multiple system atrophy (MSA) and diseases defined by pathological 43-kDa transactive response DNA-binding protein (TDP-43) or fused in sarcoma (FUS) aggregates such as amyotrophic lateral sclerosis and frontotemporal lobar degeneration show overlapping clinico-pathological features. Consequently, we examined MSA for evidence of TDP-43 or FUS pathology utilizing immunohistochemical studies in autopsy material from 29 MSA patients. Results: TDP-43 pathology was generally rare, and there were no FUS lesions. The TDP-43 lesions were located predominantly in medio-temporal lobe and subcortical brain
\end{abstract}

areas and were comprised mainly of dystrophic processes and perivascular (and subpial) lesions. Conclusions: The multisystem clinical symptoms and signs of MSA, and in particular the neurobehavioural/cognitive and pyramidal features, appear not to result from concomitant TDP-43 or FUS pathology, but rather from widespread white matter $\alpha$-synuclein positive glial cytoplasmic inclusions and neurodegeneration in keeping with a primary $\alpha$ synuclein-mediated oligodendrogliopathy. The gliodegenerative disease MSA evidently results from different pathogenetic mechanisms than neurodegenerative diseases linked to pathological TDP-43.

Keywords: 43-kDa transactive response DNA-binding protein, multiple system atrophy

\section{Introduction}

Multiple system atrophy (MSA) is a sporadic rapidly progressive multisystem neurodegenerative disorder of adult onset and unknown aetiology. The four classic clinical features of MSA include autonomic failure, parkinsonism,

Correspondence: John Trojanowski, Department of Pathology and Laboratory Medicine, University of Pennsylvania School of Medicine, HUP, Maloney 3rd Floor, 36th and Spruce Streets, Philadelphia, PA 19104-4283, USA. Tel: +1 215662 6399; Fax: +1 215349 5909; E-mail: trojanow@mail.med.upenn.edu

The authors have no conflicts of interest. Felix Geser and Joseph A. Malunda contributed equally. cerebellar ataxia and pyramidal or upper motor neurone signs in various combinations [1,2]. Dysautonomia, reflecting pathology in subcortical structures such as the brainstem, has a strong impact on the quality of life in MSA [3,4] and it continues to progress over time [5]. Parkinsonian or cerebellar signs are also hallmark features of MSA, and motor neurone disease occurs less frequently [2,6-8]. Although severe cognitive dysfunction or dementia is rare in MSA, some impairments in attention or memory occur in up to about two-thirds of MSA patients [3,9]. Other neuropsychiatric features such as depression appear to be even more frequent, while

(C) 2011 The Authors Neuropathology and Applied Neurobiology (C) 2011 British Neuropathological Society 
pseudobulbar features occur in up to $30 \%$ of cases [3,10], and sleep disturbances also are common [3,9-11].

Neuropathologically, MSA is characterized by widespread involvement of the central nervous system (CNS) as evidenced mainly by $\alpha$-synuclein positive oligodendroglial cytoplasmic inclusions (GCIs), but Lewy body-like $\alpha$-synuclein positive inclusions also occur, albeit less frequently [4,12-14]. Although neurodegeneration has been reported in the pyramidal system and spinal cord as well as in various cortical and subcortical brain structures of MSA [15-20], it is not clear whether this reflects pathology specific to or independent of one of the better characterized forms of MND such as amyotrophic lateral sclerosis (ALS), with or without frontotemporal lobar degeneration (FTLD).

Recently, pathological 43-kDa transactive response DNA-binding protein (TDP-43) has been shown to be the major disease protein in ALS, FTLD with MND (FTLDMND) and FTLD with ubiquitin positive, tau and $\alpha$-synuclein negative inclusions (FTLD-U) [21-22]. Furthermore, fused in sarcoma (FUS)/translocated in liposarcoma was originally identified as a gene and protein associated with ALS, but FUS lesions have now defined FTLD-FUS as a separate subtype of FTLD that accounts for approximately $5-10 \%$ of all FTLD cases [23-25]. These advances have prompted extensive revisions in our current understanding of the relationship between ALS and FTLD, including the nosology and diagnostic neuropathology terminology for these disorders [26].

While the extent to which FUS pathology occurs in other disorders is not known, TDP-43 pathology in addition to disease defining pathological lesions has been found in virtually all neurodegenerative diseases that are characterized by tau or $\alpha$-synuclein positive inclusions such as Alzheimer's disease, Lewy body diseases, corticobasal degeneration, Pick's disease and the ALS-Parkinson Dementia Complex of Guam [27-32]. Moreover, agedependent significant TDP-43 changes in limbic brain areas have been reported in almost $30 \%$ of elderly subjects [33].

Anecdotal reports suggest that TDP-43 pathology is absent in MSA [34,35]. These results together with the dramatic recent advances in understanding the neuropathology of MND and frontotemporal dementia, as well as the overlapping clinico-pathological features of MSA with ALS and FTLD $[6,36,37]$, prompted us to examine MSA patients immunohistochemically for evidence of pathological TDP-43 and FUS deposits.

\section{Materials and methods}

\section{Study subjects}

Individuals who underwent autopsy in the Center for Neurodegenerative Disease Research at the University of Pennsylvania (UPenn) from 1995 to 2007 were enrolled. These included patients with a movement disorder found to be MSA at post mortem examination. The patients scrutinized here were longitudinally followed by UPenn investigators or as part of a consortium of MSA investigators at other institutions. Informed consent for autopsy was obtained in all cases from the patient's family or legal representative in accordance with the Commonwealth of Pennsylvania law as well as protocols approved by the UPenn Institutional Review Boards.

To screen for TDP-43 and FUS pathology, we examined multiple CNS areas (including spinal cord, rhombencepahlon, deep brain nuclei, corticoid areas, allo-, meso- and neocortex) by immunohistochemistry (IHC) with antibodies to TDP-43. The brain regions scrutinized included the hippocampus/transentorhinal cortex and amygdala/ periamygdaloid, as these areas are among the CNS regions most consistently affected by accumulations of TDP-43 in FTLD-TDP [22,33]. In addition, the spinal cord and amygdala have been evaluated for evidence of FUS pathology.

\section{IHC}

All cases were fully examined by diagnostic techniques to establish a diagnosis of MSA as described [21,22,29,38] in accordance with the recently revised neuropathology criteria for MSA [12]. Briefly, small blocks of freshly dissected tissues from multiple CNS areas were fixed in $10 \%$ neutral buffered formalin or $70 \%$ ethanol with $150 \mathrm{mM} \mathrm{NaCl}$, paraffin-embedded, and cut into $6 \mu \mathrm{m}$ sections. Sections were subjected to IHC using the avidin-biotin complex detection method (Vectastatin ABC kit, Vector Laboratories, Burlingame, CA, USA) and, in a proportion of the material, the BioGenex Super Sensitive Detection System Kit (BioGenex Laboratories, San Ramon, CA, USA), with 3,3-diaminobenzidine as the chromogen. The following primary antibodies were used: mouse anti-paired helical filament monoclonal antibody (mAb; a gift of Peter Davies; 1:1000), mouse anti-ubiquitin $\mathrm{mAb}$ (1510, Chemicon, Temecula, CA, USA; 1:100 000), rabbit polyclonal antiTDP-43 (Protein-Tech Group, Chicago, IL, USA; 1:4500),

(C) 2011 The Authors

Neuropathology and Applied Neurobiology (C) 2011 British Neuropathological Society, 37, 358-365 
rat anti-phosphorylated TDP-43 mAb (S409/410 [38], 1:1000), mouse anti- $\alpha$-synuclein $\mathrm{mAb}$ (Syn303, generated in the Center for Neurodegenerative Disease Research, Philadelphia, PA, USA; 1:4000), rabbit polyclonal anti-FUS antibody (Sigma-Aldrich, Saint Louis, MO, USA; 1:400). Sections stained for ubiquitin, TDP-43 and FUS were pretreated by boiling in citrate antigen unmasking solution (Vector Laboratories, Burlingame, CA, USA; 1:100) using a microwave, and those stained for $\alpha$-synuclein were pretreated with $80 \%$ formic acid (as was a subset of sections stained for TDP-43). Double-labelling immunofluorescence IHC using Alexa Fluor 488 and 594 conjugated secondary antibodies (Molecular Probes, Eugene, OR, USA) was performed as previously described [21,29]. Positive controls were human disease CNS tissue sections with known pathological reactivity to the antibody in question, and they were included in every IHC staining procedure as described previously $[21,22,29,38]$. Further, normal nuclear TDP-43 staining in unaffected regions of CNS sections served as internal controls for each slide. Images of IHC were obtained using an Olympus BX 51 (Tokyo, Japan) microscope using a digital camera-DP71 (Olympus, Orangeburg, NY, USA), and DP manager (Olympus, Orangeburg, NY, USA). Digital images of immunofluorescence were obtained using a Nikon TE2000 microscope and were captured with a CoolSNAP Monochrome camera (Photometrics, Tucson, AZ, USA) and Metamorph (Molecular Devices, Downingtown, PA, USA) software.

\section{Evaluation of pathology}

TDP-43 inclusions were assessed based on morphologies and distribution in a given brain area as described elsewhere [22,39]. We rated FUS and TDP-43 pathology by means of a 5 -point ordinal scale $(0$, none; 1 , rare/minor; 2 , mild; 3 , moderate; 4 , severe/numerous). We adopted the assessment of pathology using an ordinal scale rather than by applying numeric image analysis-based quantification tools, as the former acknowledges the sequential nature of stages of increasing severity, ultimately corresponding to a spread of pathology throughout the brain as described previously [33]. In fact, ordinal data provide information about severity stages rather than serving as a measurement acknowledging that one stage follows continuously into the other.

\section{Statistical analyses}

The data were analysed using spss 16.0 for Windows (SPSS, Inc., Chicago, IL, USA). The 'average' (and 'spread') of data on patient characteristics was estimated by calculating the median (and 25th to 75 th percentiles).

\section{Results}

The examined cohort included 29 patients with pathologically confirmed MSA ( 9 female and 22 male patients) with a median age of death of 67 years (interquartile range: 60-74 years). The post mortem interval was $16 \mathrm{~h}$ (10.5$19.5 \mathrm{~h}$ ). All cases showed changes consistent with a diagnosis of MSA including $\alpha$-synuclein positive oligodendroglial inclusions associated with neuronal loss and gliosis as defined by the recently revised neuropathology criteria for MSA [14]. The brain areas examined for pathological TDP-43 include the following: spinal cord $(n=26)$, medulla $(n=24)$, midbrain $(n=27)$, pons $(n=26)$, cerebellum grey matter, white matter and dentate gyrus $(n=23)$, lentiform nucleus/striatum $(n=27)$, motor gyrus grey and white matter $(n=28)$, amygdala $(n=27)$, hippocampus dentate gyrus and CA1-CA4/ subiculum $(n=29)$, (trans-)entorhinal grey and white matter $(n=29)$, periamygdaloid grey matter $(n=27)$, periamygdaloid white matter $(n=26)$, superior temporal gyrus grey and white matter $(n=26)$, frontal gyrus grey and white matter $(n=28)$. Further, the amygdala/ periamygdaloid region and spinal cord were examined for evidence of FUS pathology in 25 cases. TDP-43 pathology was found generally to a low degree (Figure 1), and Table 1 shows the cases with at least a mild level of TDP- 43 pathology. The disease duration of these cases did not differ as compared with the remaining patients, that is 7.8 (4.612.8 ) vs. 7.0 (5-9.2) years, $P=0.973$. Further, the prevalence of additional 'ageing-related' pathologies such as tau or amyloid- $\beta$ lesions assessed in the diagnostic work up did not show an apparent difference between these groups. Several additional cases showed rare or minor pathology, that is single events such as dystrophic cellular process, or even more equivocal TDP-43 immunoreactivity. No cases showed FUS pathology. The TDP-43 inclusions were located predominantly in subcortical brain areas such as the amygdala, midbrain or medulla oblongata. There was almost no neocortical (that is frontotemporal) TDP-43 pathology detected. TDP-43 pathology comprised mainly dystrophic cellular processes - either in the form of thin dystrophic neurites or thicker axonal spheroid-like structures, or grain-like structures. Cytoplasmic TDP-43 immunoreactivity was encountered only rarely. There was no unequivocal evidence of TDP-43 immunoreactivity of 

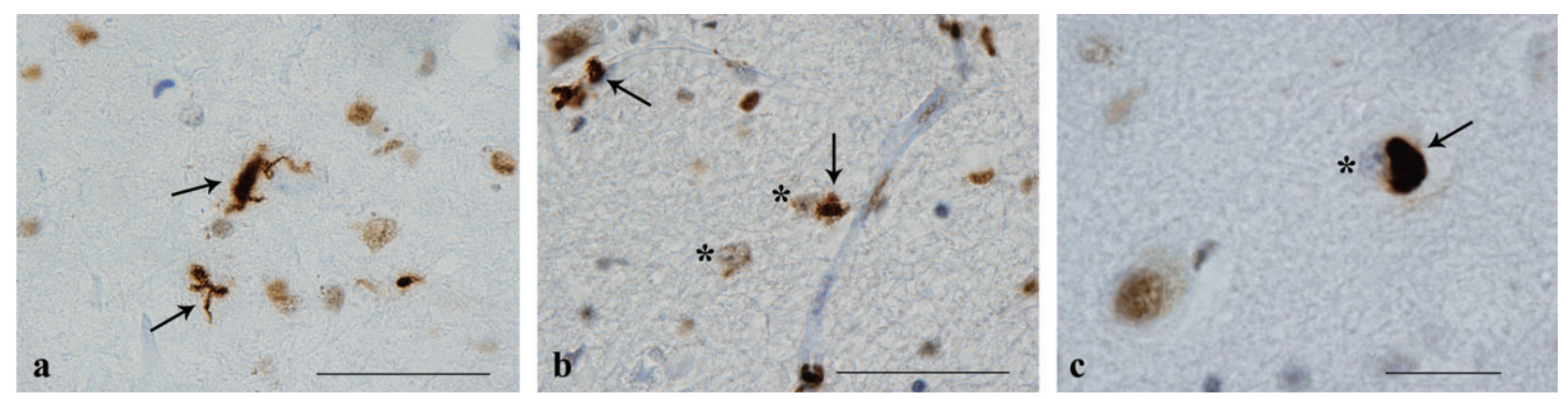

Figure 1. Spectrum of 43-kDa transactive response DNA-binding protein (TDP-43) pathology in multiple system atrophy. Small focus of TDP-43 positive dystrophic cellular processes (arrows) in the midbrain (a) $($ bar $=50 \mu \mathrm{m})$, perivascular TDP-43 pathology (arrows) $(\mathbf{b})$ (bar $=50 \mu \mathrm{m}$ ) and neuronal cytoplasmic inclusion (arrow) in the periamygdaloid cortex (c) $(\mathrm{bar}=20 \mu \mathrm{m})$. Note the absence of normal nuclear TDP-43 immunoreactivity ('nuclear clearing', asterisk) in b and c.

Table 1. Low level subcortical TDP-43 pathology in multiple system atrophy

\begin{tabular}{|c|c|c|c|c|c|c|c|c|c|c|c|c|}
\hline \multirow[b]{2}{*}{ Case Nr. } & \multicolumn{3}{|l|}{ Med } & \multirow[b]{2}{*}{ Pon } & \multicolumn{2}{|l|}{ Mid } & \multirow[t]{2}{*}{ Tra-ent } & \multicolumn{2}{|l|}{ Hip } & \multirow[b]{2}{*}{ Amy } & \multicolumn{2}{|l|}{ Per } \\
\hline & Dor & $\operatorname{Inf}$ & Oth & & Sub & Oth & & $C A S$ & Den & & Gre & Whi \\
\hline 1 & \multicolumn{3}{|c|}{$\mathrm{D}$} & & & & & & & \multicolumn{2}{|c|}{$\mathrm{D}, \mathrm{G}, \mathrm{P}$} & \\
\hline 2 & & & & & & & \multicolumn{2}{|c|}{ S, C, D, P* } & & $\mathrm{D}$ & $\mathrm{D} \dagger, \mathrm{G}, \mathrm{P}, \mathrm{S}, \mathrm{C}$ & \\
\hline 3 & $\mathrm{D}, \mathrm{S}, \mathrm{P}$ & & & & & & $\mathrm{D}, \mathrm{P}, \mathrm{S}^{*}$ & & & \multicolumn{2}{|c|}{$\mathrm{P}, \mathrm{D}^{*}$} & \\
\hline 4 & & & & & & $\mathrm{D}, \mathrm{P}, \mathrm{C}$ & & & & & & \\
\hline
\end{tabular}

*Mild or †moderate subpial dystrophic cellular processes in the in area of high density of corpora amylacea.

Only cases with a minimum degree of mild pathology are shown here; several additional cases showed rare pathology in brain areas such as the brainstem, amygdala and hippocampus.

Merged boxes denote transition between these brain areas.

Cellular localization of TDP-43 pathology: G, TDP-43 positive grain; D, dystrophic cellular process; C, cytoplasmic TDP-43 pathology.

Pattern of TDP-43 pathology (if applicable) ${ }^{33}$ : P, perivascular TDP-43 pathology; S, superficial TDP-43 pathology.

$\square$ none; $\square$ rare; $\square$ mild; $\square$ moderate; $\square$ severe; $\square$ not done.

Med, medulla; Dor, dorsal motor plate; Inf, inferior olive; Oth, other; Pon, pons; Mid, midbrain; Sub, substantia nigra; Tra-ent, (Trans-)entorhinal cortex; Hip, hippocampus; CAS, CA4-CA1-subiculum; Den, dentate gyrus; Amy, amygdala; Per, periamygdaloid region; Gre, grey matter; Whi, white matter.

GCIs in 3,3-diaminobenzidine IHC. Double-labelling immunofluorescence studies showed that GCIs are $\alpha$ synuclein positive and TDP-43 negative (Figure 2). None of the cases showed severe neuronal loss and gliosis in the CA-1/subiculum formation of the hippocampus that would suggest hippocampal sclerosis.

\section{Discussion}

Based on the overlap of clinico-pathological features between ALS and FTLD-TDP on the one hand and MSA on the other, we examined a cohort of pathologically proven MSA cases for evidence of TDP-43 and FUS pathology. We show here that overall there is rare TDP-43 pathology, found predominantly in mediotemporal lobe and subcortical brain areas. The extent to which this TDP-43 pathology contributes to the clinical phenotype of MSA, in particular the neuropsychiatric or extrapyramidal motor features, is uncertain; however, a major role seems unlikely. For example, in comparison with this study, varying degrees of pathology of all the major diagnostic proteins including tau, amyloid- $\beta$ and $\alpha$-synuclein related pathological aggregates have been found in the CNS of an elderly, neurological and cognitive normal or only mildly impaired population [40,41], and these types of pathologies are rare in MSA [42,43]. Moreover, we recently showed significant TDP-43 pathology in 30\% of elderly patients with severe mental illness with/without superimposed dementia and control or cognitively mildly impaired subjects in an age-dependent manner; additionally, mild or rare TDP-43 pathology was present in about $10 \%$ or $20 \%$ of study subjects [33]. The same study also demon- 

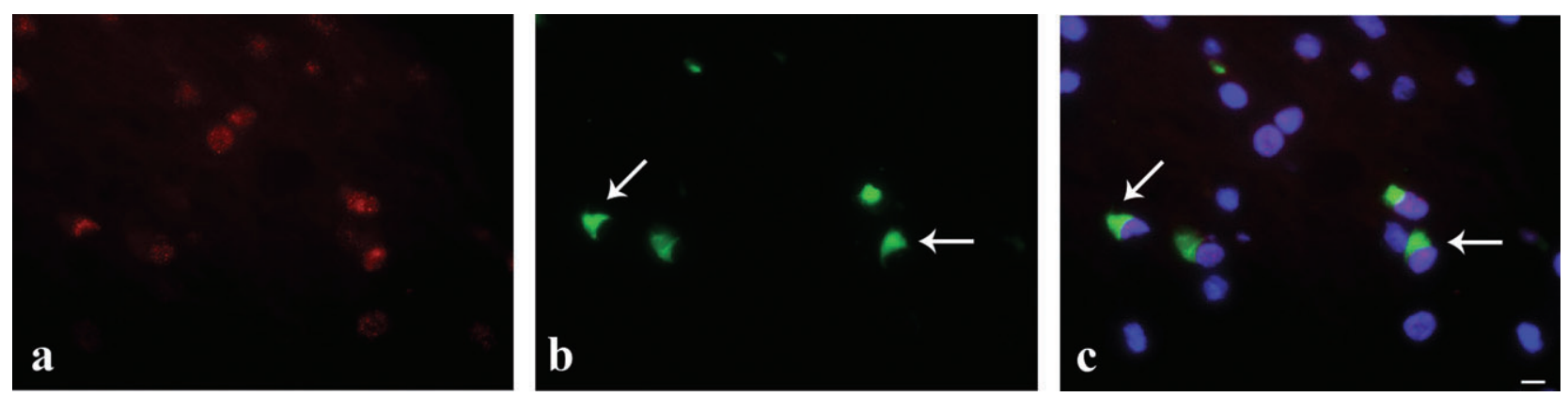

Figure 2. 43-kDa transactive response DNA-binding protein (TDP-43) and $\alpha$-synuclein co-localization experiments in multiple system atrophy. Absence of pathological TDP-43 (a) in cytoplasmic $\alpha$-synuclein (b) aggregates (e.g. arrows) in oligodendroglial cells (that is glial cytoplasmic inclusion) in the midbrain (merge in c) $($ bar $=10 \mu \mathrm{m})$.

strated that TDP-43 pathology can be grouped into four morphological patterns, that is: (i) subpial and subependymal; (ii) focal or (iii) diffuse lesions in deep brain parenchyma; and (iv) perivascular pathology. The evidence of infrequent pathologic TDP-43 in our MSA cohort including mainly dystrophic cellular processes and the perivascular lesions corroborate our previous study on patients with severe mental illness and elderly controls [33] and implies that these changes are among the earliest in the time course of the TDP- 43 proteinopathy and/or are 'agerelated'. The finding of a lower degree of TDP-43 pathology in the MSA as compared with the elderly cohort might be due to the younger age at death in the MSA group with the difference being about 10 years. TDP-43 pathology in addition to the disease defining pathology has been reported in almost all of the major neurodegenerative disease groups including tauopathies and $\alpha$ synucleinopathies (for review see [32]). Indeed, it was previously suggested that in advanced Alzheimer's disease, medial temporal lobe limbic structures are vulnerable to TDP-43 pathology and the amygdala is the most susceptible region. This implies a progression of TDP-43 pathology, with higher-order association cortices affected only later in the disease process (or in a subset of cases) and other limbic brain areas occupying an intermediate position $[32,44]$; the likewise topographical distribution might apply to early FTLD cases or subclinical patients as shown by our recent study [33]. The almost complete absence of neocortical (such as frontotemporal) TDP-43 pathology in our MSA cohort supports this concept, and the finding of overall rare TDP-43 pathology in several different brain areas corroborates the multisystem idea of TDP-43 proteinopathies [22]. The absence of TDP-43 pathology in the motor cortex and spinal cord suggests that MND in MSA results from causes other than pathological TDP-43. There are various reports in the literature on degeneration of the motor cortex and spinal cord and/or of other cortical and subcortical structures in MSA [15-20,36,37,45-48]. The absence of TDP-43 pathology in previous studies on MSA could be due to the small number of cases examined or limited number of brain areas assessed [34,35].

The term 'atypical FTLD-U' was recently coined to denote sporadic early-onset frontotemporal dementia with severe progressive behavioural and personality changes [49,50], and was associated with FUS inclusion pathology [23]. Despite a few clinical similarities between MSA and atypical FTLD-U, FUS pathology was not present in the MSA patients studied here implying different disease mechanisms between these two disorders.

We conclude that the multisystem clinical symptoms and signs of MSA, in particular the neurobehavioral/ cognitive and pyramidal features, appear not to be due to concomitant TDP-43 or FUS pathology, but rather from widespread white matter $\alpha$-synuclein positive GCIs, degeneration and neurone loss consistent with the concept of a primary $\alpha$-synuclein-mediated oligodendrogliopathy. Thus, MSA is a gliodegenerative $\alpha$-synucleinopathy that is distinct from neurodegenerative diseases linked to pathological FUS or TDP-43.

\section{Acknowledgements}

This work was funded by grants from the National Institutes of Health (AG-10124, AG-17586 and NS044233, NS 32352, NS 44233, NS 22352, NS 43364), Mayo CTSA (UL1 RR24150) and Mayo Funds. Dr Virginia M.-Y. Lee is the John H. Ware III Chair of Alzheimer's Research 
and Dr John Q. Trojanowski is the William Maul MeaseyTruman G. Schnabel, Jr., MD Professor of Geriatric Medicine and Gerontology. Dr Sid Gilman is the William J. Herdman Distinguished University Professor of Neurology. Dr Gregor K. Wenning is Professor of Neurology and Clinical Neurobiology and he has received a Neuroscience Centre Grant by the Federal Ministry of Education and Science, Vienna, Austria. We thank the families of patients whose generosity made this research possible. We also thank Dr Manuela Neumann for providing us with the antiphosporylated TDP-43 antibody (S409/410), John Robinson, BS, for the comments on the manuscript, and our colleagues at the Center for Neurodegenerative Disease Research and Department of Psychiatry, University of Pennsylvania School of Medicine, for their technical support and advice, particularly Theresa Schuck, BA, Lauren Stutzbach, BA, Michael Partain, BA and Mfon Umoh.

\section{References}

1 Wenning GK, Colosimo C, Geser F, Poewe W. Multiple system atrophy. Lancet Neurol 2004; 3: 93-103

2 Gilman S, Wenning GK, Low PA, Brooks DJ, Mathias CJ, Trojanowski JQ, Wood NW, Colosimo C, Durr A, Fowler CJ, Kaufmann H, Klockgether T, Lees A, Poewe W, Quinn N, Revesz T, Robertson D, Sandroni P, Seppi K, Vidailhet M. Second consensus statement on the diagnosis of multiple system atrophy. Neurology 2008; 71: 670-6

3 Schrag A, Geser F, Stampfer-Kountchev M, Seppi K, Sawires M, Kollensperger M, Scherfler C, Quinn N, Pellecchia MT, Barone P, Del Sorbo F, Albanese A, Ostergaard K, Dupont E, Cardozo A, Tolosa E, Nilsson CF, Widner H, Lindvall O, Giladi N, Gurevich T, Daniels C, Deuschl G, Coelho M, Sampaio C, Abele M, Klockgether T, Schimke N, Eggert KM, Oertel W, Djaldetti R, Colosimo C, Meco G, Poewe W, Wenning GK. Health-related quality of life in multiple system atrophy. Mov Disord 2006; 21: 809-15

4 Ozawa T. Morphological substrate of autonomic failure and neurohormonal dysfunction in multiple system atrophy: impact on determining phenotype spectrum. Acta Neuropathol 2007; 114: 201-11

5 Kollensperger M, Stampfer-Kountchev M, Seppi K, Geser F, Frick C, Del Sorbo F, Albanese A, Gurevich T, Giladi N, Djaldetti R, Schrag A, Low PA, Mathias CJ, Poewe W, Wenning GK. Progression of dysautonomia in multiple system atrophy: a prospective study of self-perceived impairment. Eur J Neurol 2007; 14: 66-72

6 Taniwaki T, Minohara M, Hara H, Ohyagi Y, Yamada T, Kira JI. Striatonigral degeneration with motor neuron disease. J Neurol 2000; 247: 395-6

7 Geser F, Wenning GK, Seppi K, Stampfer-Kountchev M, Scherfler C, Sawires M, Frick C, Ndayisaba JP, Ulmer H,
Pellecchia MT, Barone P, Kim HT, Hooker J, Quinn NP, Cardozo A, Tolosa E, Abele M, Klockgether T, Ostergaard K, Dupont E, Schimke N, Eggert KM, Oertel W, Djaldetti R, Poewe W. Progression of multiple system atrophy (MSA): a prospective natural history study by the European MSA Study Group (EMSA SG). Mov Disord 2006; 21: 179-86

8 Geser F, Seppi K, Stampfer-Kountchev M, Kollensperger M, Diem A, Ndayisaba JP, Ostergaard K, Dupont E, Cardozo A, Tolosa E, Abele M, Dodel R, Klockgether T, Ghorayeb I, Yekhlef F, Tison F, Daniels C, Kopper F, Deuschl G, Coelho M, Ferreira J, Rosa MM, Sampaio C, Bozi M, Schrag A, Hooker J, Kim H, Scaravilli T, Mathias CJ, Fowler C, Wood N, Quinn N, Widner H, Nilsson CF, Lindvall O, Schimke N, Eggert KM, Oertel W, Del Sorbo F, Carella F, Albanese A, Pellecchia MT, Barone P, Djaldetti R, Meco G, Colosimo C, Gonzalez-Mandly A, Berciano J, Gurevich T, Giladi N, Galitzky M, Ory F, Rascol O, Kamm C, Buerk K, Maass S, Gasser T, Poewe W, Wenning GK. The European Multiple System Atrophy-Study Group (EMSA-SG). J Neural Transm 2005; 112: 1677-86

9 Colosimo C, Morgante L, Antonini A, Barone P, Avarello TP, Bottacchi E, Cannas A, Ceravolo MG, Ceravolo R, Cicarelli G, Gaglio RM, Giglia L, Iemolo F, Manfredi M, Meco G, Nicoletti A, Pederzoli M, Petrone A, Pisani A, Pontieri FE, Quatrale R, Ramat S, Scala R, Volpe G, Zappulla S, Bentivoglio AR, Stocchi F, Trianni G, Del Dotto P, Simoni L, Marconi R. Non-motor symptoms in atypical and secondary parkinsonism: the PRIAMO study. J Neurol 2010; 257: 5-14

10 Kollensperger M, Geser F, Seppi K, Stampfer-Kountchev M, Sawires M, Scherfler C, Boesch S, Mueller J, Koukouni V, Quinn N, Pellecchia MT, Barone P, Schimke N, Dodel R, Oertel W, Dupont E, Ostergaard K, Daniels C, Deuschl G, Gurevich T, Giladi N, Coelho M, Sampaio C, Nilsson C, Widner H, Sorbo FD, Albanese A, Cardozo A, Tolosa E, Abele M, Klockgether T, Kamm C, Gasser T, Djaldetti R, Colosimo C, Meco G, Schrag A, Poewe W, Wenning GK. Red flags for multiple system atrophy. Mov Disord 2008; 23: 1093-9

11 Nam H, Hong YH, Kwon HM, Cho J. Does multiple system atrophy itself affect sleep structure? Neurologist 2009; 15: 274-6

12 Trojanowski JQ, Revesz T. Proposed neuropathological criteria for the post mortem diagnosis of multiple system atrophy. Neuropathol Appl Neurobiol 2007; 33: 615-20

13 Geser F, Jellinger K, Köllensperger M, Stevanova N, Wenning GK. Multiple system atrophy. Etiology, pathology, and pathogenesis. In Movement Disorders IV - Blue Books of Neurology Series. Eds AHV Schapira, AET Lang, S Fahn. Philadelphia: Saunders Elsevier, 2010; 32139

14 Tu PH, Galvin JE, Baba M, Giasson B, Tomita T, Leight S, Nakajo S, Iwatsubo T, Trojanowski JQ, Lee VM. Glial cytoplasmic inclusions in white matter oligodendrocytes of multiple system atrophy brains contain insoluble alphasynuclein. Ann Neurol 1998; 44: 415-22 
15 Wenning GK, Tison F, Ben Shlomo Y, Daniel SE, Quinn NP. Multiple system atrophy: a review of 203 pathologically proven cases. Mov Disord 1997; 12: 133-47

16 Konno H, Yamamoto T, Iwasaki Y, Iizuka H. Shy-Drager syndrome and amyotrophic lateral sclerosis. Cytoarchitectonic and morphometric studies of sacral autonomic neurons. J Neurol Sci 1986; 73: 193-204

$17 \mathrm{Su} \mathrm{M}$, Yoshida Y, Hirata Y, Watahiki Y, Nagata K. Primary involvement of the motor area in association with the nigrostriatal pathway in multiple system atrophy: neuropathological and morphometric evaluations. Acta Neuropathol 2001; 101: 57-64

18 Tsuchiya K, Ozawa E, Haga C, Watabiki S, Ikeda M, Sano M, Ooe K, Taki K, Ikeda K. Constant involvement of the Betz cells and pyramidal tract in multiple system atrophy: a clinicopathological study of seven autopsy cases. Acta Neuropathol 2000; 99: 628-36

19 Wakabayashi K, Ikeuchi T, Ishikawa A, Takahashi H. Multiple system atrophy with severe involvement of the motor cortical areas and cerebral white matter. J Neurol Sci 1998; 156: 114-17

20 Wenning GK, Ben Shlomo Y, Magalhaes M, Daniel SE, Quinn NP. Clinicopathological study of 35 cases of multiple system atrophy. J Neurol Neurosurg Psychiatry 1995; 58: 160-6

21 Neumann M, Sampathu DM, Kwong LK, Truax AC, Micsenyi MC, Chou TT, Bruce J, Schuck T, Grossman M, Clark CM, McCluskey LF, Miller BL, Masliah E, Mackenzie IR, Feldman H, Feiden W, Kretzschmar HA, Trojanowski JQ, Lee VM-Y. Ubiquitinated TDP-43 in frontotemporal lobar degeneration and amyotrophic lateral sclerosis. Science 2006; 314: 130-3

22 Geser F, Martinez-Lage M, Robinson J, Uryu K, Neumann M, Brandmeir NJ, Xie SX, Kwong LK, Elman L, McCluskey L, Clark CM, Malunda J, Miller BL, Zimmerman EA, Qian J, Van DV, Grossman M, Lee VM, Trojanowski JQ. Clinical and pathological continuum of multisystem TDP-43 proteinopathies. Arch Neurol 2009; 66: 180-9

23 Neumann M, Rademakers R, Roeber S, Baker M, Kretzschmar HA, Mackenzie IR. A new subtype of frontotemporal lobar degeneration with FUS pathology. Brain 2009; 132: 2922-31

24 Kwiatkowski TJ Jr, Bosco DA, LeClerc AL, Tamrazian E, Vanderburg CR, Russ C, Davis A, Gilchrist J, Kasarskis EJ, Munsat T, Valdmanis P, Rouleau GA, Hosler BA, Cortelli P, de Jong PJ, Yoshinaga Y, Haines JL, Pericak-Vance MA, Yan J, Ticozzi N, Siddique T, McKenna-Yasek D, Sapp PC, Horvitz HR, Landers JE, Brown RH Jr. Mutations in the FUS/TLS gene on chromosome 16 cause familial amyotrophic lateral sclerosis. Science 2009; 323: 1205-8

25 Vance C, Rogelj B, Hortobagyi T, De Vos KJ, Nishimura AL, Sreedharan J, Hu X, Smith B, Ruddy D, Wright P, Ganesalingam J, Williams KL, Tripathi V, Al Saraj S, Al Chalabi A, Leigh PN, Blair IP, Nicholson G, de Belleroche J, Gallo JM, Miller CC, Shaw CE. Mutations in FUS, an RNA processing protein, cause familial amyotrophic lateral sclerosis type 6. Science 2009; 323: 120811

26 Mackenzie IR, Neumann M, Bigio EH, Cairns NJ, Alafuzoff I, Kril J, Kovacs GG, Ghetti B, Halliday G, Holm IE, Ince PG, Kamphorst W, Revesz T, Rozemuller AJ, KumarSingh S, Akiyama H, Baborie A, Spina S, Dickson DW, Trojanowski JQ, Mann DM. Nomenclature and nosology for neuropathologic subtypes of frontotemporal lobar degeneration: an update. Acta Neuropathol 2010; 119: $1-4$

27 Amador-Ortiz C, Lin WL, Ahmed Z, Personett D, Davies P, Duara R, Graff-Radford NR, Hutton ML, Dickson DW. TDP-43 immunoreactivity in hippocampal sclerosis and Alzheimer's disease. Ann Neurol 2007; 61: 435-45

28 Nakashima-Yasuda H, Uryu K, Robinson J, Xie SX, Hurtig H, Duda JE, Arnold SE, Siderowf A, Grossman M, Leverenz JB, Woltjer R, Lopez OL, Hamilton R, Tsuang DW, Galasko D, Masliah E, Kaye J, Clark CM, Montine TJ, Lee VM, Trojanowski JQ. Co-morbidity of TDP-43 proteinopathy in Lewy body related diseases. Acta Neuropathol 2007; 114: 221-9

29 Uryu K, Nakashima-Yasuda H, Forman MS, Kwong LK, Clark CM, Grossman M, Miller BL, Kretzschmar HA, Lee VM, Trojanowski JQ, Neumann M. Concomitant TARDNA-binding protein 43 pathology is present in Alzheimer disease and corticobasal degeneration but not in other tauopathies. J Neuropathol Exp Neurol 2008; 67: 555-64

30 Higashi S, Iseki E, Yamamoto R, Minegishi M, Hino H, Fujisawa K, Togo T, Katsuse O, Uchikado H, Furukawa Y, Kosaka K, Arai H. Concurrence of TDP-43, tau and alpha-synuclein pathology in brains of Alzheimer's disease and dementia with Lewy bodies. Brain Res 2007; 1184: 284-94

31 Geser F, Winton MJ, Kwong LK, Xu Y, Xie SX, Igaz LM, Garruto RM, Perl DP, Galasko D, Lee VM, Trojanowski JQ. Pathological TDP-43 in parkinsonism-dementia complex and amyotrophic lateral sclerosis of Guam. Acta Neuropathol 2008; 115: 133-45

32 Geser F, Martinez-Lage M, Kwong LK, Lee VM, Trojanowski JQ. Amyotrophic lateral sclerosis, frontotemporal dementia and beyond: the TDP-43 diseases. I Neurol 2009; 256: 1205-14

33 Geser F, Robinson JL, Malunda JA, Xie SX, Clark CM, Kwong LK, Moberg PJ, Moore E, Van Deerlin VM, Lee VMY, Arnold SE, Trojanowski JQ. Pathological TDP-43 in older adults with and without severe mental illness. Arch Neurol 2010; 67: 1238-50

34 Cairns NJ, Neumann M, Bigio EH, Holm IE, Troost D, Hatanpaa KJ, Foong C, White CL III, Schneider JA, Kretzschmar HA, Carter D, Taylor-Reinwald L, Paulsmeyer K, Strider J, Gitcho M, Goate AM, Morris JC, Mishra M, Kwong LK, Stieber A, Xu Y, Forman MS, Trojanowski JQ, Lee VM, Mackenzie IR. TDP-43 in familial and sporadic frontotemporal lobar degeneration with ubiquitin inclusions. Am J Pathol 2007; 171: 227-40 
35 King A, Sweeney F, Bodi I, Troakes C, Maekawa S, Al Sarraj S. Abnormal TDP-43 expression is identified in the neocortex in cases of dementia pugilistica, but is mainly confined to the limbic system when identified in high and moderate stages of Alzheimer's disease. Neuropathology 2010; 30: 408-19

36 Konagaya M, Konagaya Y, Sakai M, Matsuoka Y, Hashizume Y. Progressive cerebral atrophy in multiple system atrophy. J Neurol Sci 2002; 195: 123-7

37 Sudo S, Fukutani Y, Matsubara R, Sasaki K, Shiozawa M, Wada Y, Naiki H, Isaki K. Motor neuron disease with dementia combined with degeneration of striatonigral and pallidoluysian systems. Acta Neuropathol 2002; 103: 521-5

38 Neumann M, Kwong LK, Lee EB, Kremmer E, Flatley A, $\mathrm{Xu}$ Y, Forman MS, Troost D, Kretzschmar HA, Trojanowski JQ, Lee VM. Phosphorylation of S409/410 of TDP-43 is a consistent feature in all sporadic and familial forms of TDP-43 proteinopathies. Acta Neuropathol 2009; 117: $137-49$

39 Brandmeir NJ, Geser F, Kwong LK, Zimmerman E, Qian J, Lee VM, Trojanowski JQ. Severe subcortical TDP-43 pathology in sporadic frontotemporal lobar degeneration with motor neuron disease. Acta Neuropathol 2008; 115: 123-31

40 Del Tredici K, Rub U, de Vos RA, Bohl JR, Braak H. Where does parkinson disease pathology begin in the brain? J Neuropathol Exp Neurol 2002; 61: 413-26

41 Price JL, Morris JC. Tangles and plaques in nondemented aging and 'preclinical' Alzheimer's disease. Ann Neurol 1999; 45: 358-68

42 Takanashi M, Ohta S, Matsuoka S, Mori H, Mizuno Y. Mixed multiple system atrophy and progressive supranuclear palsy: a clinical and pathological report of one case. Acta Neuropathol 2002; 103: 82-7

43 Soper J, Trojanowski JQ, Lee VMY. Alpha-synuclein in Parkinson's disease. In Parkinson's Disease: Genetics and
Pathogenesis. Ed. T Dawson. New York: Marcel Dekker, 2010; 167-86

$44 \mathrm{Hu}$ WT, Josephs KA, Knopman DS, Boeve BF, Dickson DW, Petersen RC, Parisi JE. Temporal lobar predominance of TDP-43 neuronal cytoplasmic inclusions in Alzheimer disease. Acta Neuropathol 2008; 116: 215-20

45 Sima AA, Caplan M, D’Amato CJ, Pevzner M, Furlong JW. Fulminant multiple system atrophy in a young adult presenting as motor neuron disease. Neurology 1993; 43: 2031-5

46 Shy GM, Drager GA. A neurological syndrome associated with orthostatic hypotension: a clinical-pathologic study. Arch Neurol 1960; 2: 511-27

47 Terao S, Sobue G, Hashizume Y, Mitsuma T, Takahashi A. Disease-specific patterns of neuronal loss in the spinal ventral horn in amyotrophic lateral sclerosis, multiple system atrophy and X-linked recessive bulbospinal neuronopathy, with special reference to the loss of small neurons in the intermediate zone. J Neurol 1994; 241: 196-203

48 Konagaya M, Sakai M, Matsuoka Y, Konagaya Y, Hashizume Y. Multiple system atrophy with remarkable frontal lobe atrophy. Acta Neuropathol 1999; 97: 423-8

49 Mackenzie IR, Foti D, Woulfe J, Hurwitz TA. Atypical frontotemporal lobar degeneration with ubiquitin-positive, TDP-43-negative neuronal inclusions. Brain 2008; 131: 1282-93

50 Roeber S, Mackenzie IR, Kretzschmar HA, Neumann M. TDP-43-negative FTLD-U is a significant new clinicopathological subtype of FTLD. Acta Neuropathol 2008; 116: $147-57$

Received 6 May 2010

Accepted after revision 5 October 2010

Published online Article Accepted on 13 October 2010 